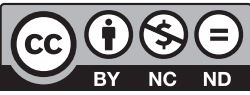

Estudos Teológicos foi licenciado com uma Licença Creative Commons Atribuição - NãoComercial - SemDerivados 3.0 Não Adaptada

http://dx.doi.org/10.22351/et.v60i3.4069

\title{
Martim Lutero em Estudos Teológicos: RESGATANDO TRINTA ANOS DE TEOLOGIA LUTERANA (1961-1990) ${ }^{1}$
}

\author{
Martin Luther in Estudos Teológicos: \\ Researching thirty years of Lutheran theology (1961-1990)
}

\section{Wilhelm Wachholz ${ }^{2}$ Jonatan Alexandre Goltz ${ }^{3}$}

Resumo: No contexto dos sessenta anos de Estudos Teológicos, este artigo busca resgatar estudos sobre a teologia de Lutero e teologia luterana apresentados no período de 1961 e 1990. Selecionamos e analisamos os artigos utilizando como critério principal a referência a Martim Lutero e sua teologia, na perspectiva da interpretação da Reforma enquanto evento, alusão ao reformador no contexto do seu quingentésimo aniversário de nascimento (1983) e estudos que apresentam releituras de Lutero na perspectiva do ecumenismo, da América Latina e, em particular, da Igreja Evangélica de Confissão Luterana no Brasil - IECLB.

Palavras-chave: Estudos Teológicos. Lutero. Ecumenismo. América Latina. Luteranismo.

Abstract: In the context of sixty years of Theological Studies, this article seeks to rescue studies on Luther's theology and Lutheran theology presented in the period of 1961 and 1990. We selected and analyzed the articles, using as reference the name of Martin Luther and his theology in the perspective of the interpretation of the Reformation as an event, an allusion to the reformer in the context of his 500th birthday (1983) and studies that present Luther reinterpretations from the perspective of ecumenism, from Latin America and, in particular, from the Evangelical Church of Lutheran Confession in Brazil - IECLB.

Keywords: Estudos Teológicos. Luther. Ecumenism. Latin America. Lutheranism.

1 O artigo foi recebido em 24 de junho de 2020 e aprovado em 21 de novembro de 2020 com base nas avaliações dos pareceristas ad hoc.

2 Doutor. Faculdades EST. E-mail: wachholz@est.edu.br

3 Bolsista de iniciação científica do CNPq. Faculdades EST. E-mail: jonatangoltzmec@gmail.com 


\section{Introdução}

A revista Estudos Teológicos surgiu no contexto da então denominada Escola/ Faculdade de Teologia, hoje Faculdades EST. Em conexão com a fundação da então Escola de Teologia (1946), foi publicado um livro intitulado "Luther vive"4, considerado uma espécie de "certidão de nascimento" da escola. A revista Estudos Teológi$\cos$, que surgiu 15 anos mais tarde com a missão de testemunhar a pesquisa da Escola/ Faculdade de Teologia/Escola Superior de Teologia/Faculdades EST, evidencia que Lutero viveu e foi reavivado na revista por meio de releituras de sua teologia em diálogo com o continente latino-americano. O objetivo deste artigo é resgatar estudos sobre a teologia de Lutero e a teologia luterana apresentados no período de 1961 e 1990 na revista Estudos Teológicos, no contexto de seus sessenta anos de existência. Selecionamos e analisamos os artigos utilizando como critério principal a referência feita a Martim Lutero e sua teologia, (1) na perspectiva da interpretação da Reforma, (2) alusão ao reformador no contexto do seu quingentésimo aniversário de nascimento (1983) e (3) estudos que apresentam releituras da teologia de Lutero em diálogo com o ecumenismo, (4) a realidade da América Latina e, (5) em particular, da Igreja Evangélica de Confissão Luterana no Brasil - IECLB. A análise dos artigos sob os critérios arrolados evidencia como a teologia de Lutero é recepcionada e relida para o contexto brasileiro e, mais amplamente, latino-americano.

\section{Lutero e a interpretação da Reforma}

Um primeiro e muito significativo artigo sobre o "evento fundante" da Reforma, a saber, a publicação das 95 teses de Martim Lutero, é apresentado em Estudos Teológicos no ano de 1967. Trata-se do artigo de Franz Lau sobre $A$ afixação das teses de Lutero: Lenda ou Fato?. Lau discute sobre a afixação das 95 teses por Lutero na porta da Igreja do Castelo de Wittenberg no dia 31 de outubro de 1517. Contextualizando, o autor recorda ter presenciado,

por ocasião da $3^{\text {a }}$ Assembleia Geral da Federação Mundial Luterana [verão de 1957], como um carro alegórico era conduzido através das ruas da cidade de Minneapolis em Minnesota U.S.A. sôbre [sic!] o qual estava montado um cenário representando a porta da Igreja do Castelo de Wittenberg e um professor de Escola Dominical vestido e penteado como um monge afixava nela com marteladas impetuosas uma cópia das 95 teses de Lutero contra a indulgência ${ }^{5}$.

Lau, então, ressalta que nenhuma das testemunhas daquela "encenação 'tipicamente americana" imaginaria que, menos de dez anos depois, a discussão acadêmica se tornasse tão "acalorada", questionando a historicidade da afixação das teses. O

4 DOHMS, Hermann Gottlieb. Luther vive. São Leopoldo: Faculdade de Teologia, 1946.

5 LAU, Franz. A afixação das teses de Lutero: Lenda ou Fato? Trad. M. Siegle e M. Dreher. Estudos Teológicos, São Leopoldo, v. 7, n. 4, p. 170-185, 1967. p. 170. 
autor lembra que, ainda por ocasião do jubileu em 31 de outubro de 1957, surgira um artigo, de Hans Volz, publicado no Deutsches Pfarrerblatt, segundo o qual as teses não teriam sido publicadas no dia 31 de outubro de 1517, mas no dia seguinte, isto é, $1^{\circ}$ de novembro de 1517. Segundo Lau, o artigo de Volz provocou muito mais alvoroço no âmbito das comunidades evangélicas do que no meio acadêmico ou da historiografia. Segundo Volz, Lutero sempre teria relacionado a publicação das teses ao Dia de Todos os Santos. Contudo, passou-se a discutir se a noite anterior, isto é, 31 de outubro, faria ou não parte da mencionada festa. Desde o início, constata Lau, Kurt Aland e Heinrich Bornkmann se apresentaram contra a tese de Volz, opinando que, caso as teses realmente tenham sido afixadas, isso teria ocorrido em 31 de outubro. Ambos ainda eram de parecer que não valeria a pena discutir sobre o problema da data. Lau, então, apresenta o seguinte "estado da arte", na sua concepção:

O resultado atual da discussão me parece ser o seguinte: as teses foram provàvelmente [sic] afixadas e a visão tradicional dos fatos deverá estar mais ou menos correta. Também me parece certo o fato de que a afixação tenha ocorrido com maior probabilidade no dia 31 de outubro do que no dia $1 .^{\circ}$ de novembro. Controvérsias científicas, em muitos casos, não levam a um resultado absolutamente claro e exato. Anteriormente, já disse existir a possibilidade de que a controvérsia, em torno [sic] da afixação das teses, se resolva de uma hora para outra. Somente seria necessário que aparecesse uma impressão original das teses e que esta fosse [sic] comprovada. Os arquivos existentes também ainda não estão esgotados, no que diz respeito ao material da história eclesiástica territorial [o autor pensa na situação da Alemanha]. Por que não seria possível achar uma prova bem clara, a favor ou contra a afixação das teses? É provável que ainda haja surpresas como também decepções em tôrno [sic] dêste [sic] assunto. Por ora resta-nos esperar o decorrer do ano de 1967. Todo aquêle [sic] que já tem feito alguma descoberta, com certeza, haverá de trazê-la à tona durante o ano jubilar ${ }^{6}$.

Percebe-se que Lau discute a historicidade da afixação das teses e não a existência das mesmas. Mais de vinte anos depois, em 1988, é publicado um outro artigo, que classificamos como sendo de interpretação da Reforma. Trata-se do artigo de Joachim Fischer, intitulado Marcas Teológicas da Reforma Protestante. No artigo, o autor apresenta as características teológicas emergentes da Reforma, em particular de Martim Lutero, relacionando-as com a doutrina da justificação somente pela fé, liberdade, fé, desprendimento, renovação, hermenêutica bíblica, encarnação e espiritualidade. Fischer conclui que o movimento da Reforma deu um "novo testemunho da mensagem bíblica a respeito da justiça gratuita e libertadora de Deus", "apontou para a prioridade da palavra de Deus na vida", conclamou as pessoas à fé, que deve ser concebida como "confiança absoluta" em Deus, concebeu "a graça como relação pessoal de Deus com o ser humano", fundamentou a esperança na e para a vida a partir do e tão "somente [no] perdão de Deus", chamou a igreja cristã para "permanente renovação pela palavra de Deus", compreendeu a unidade da Igreja na "diversidade

${ }^{6}$ LAU, 1967, p. 184-185. Acentuação original preservada. 
de teologias e costumes" e, finalmente, que somente na oração e meditação é possível compreender "o verdadeiro Deus em profundidade"

No ano seguinte, em comemoração aos 500 anos do nascimento de Tomás Müntzer (1989), Joachim Fischer apresenta um estudo sobre Lutero e Müntzer, o qual, igualmente, classificamos como de interpretação da Reforma. Fischer apresenta Müntzer como engajado na causa da população oprimida na Guerra dos Camponeses, ocorrida nos anos de 1524 e 1525. Müntzer compreendeu que a Reforma deveria se concretizar por meio de uma revolução, o que o levou a lutar ao lado dos camponeses. Ele acabou morto, no contexto da derrota imposta aos camponeses. Isso leva Fischer a questionar: "Se a revolução camponesa tivesse logrado êxito, o caráter marginal com que foi tratado Müntzer dentro do luteranismo teria sido o mesmo?”. Fischer busca responder à pergunta, constatando que as interpretações no passado distorciam a figura de Müntzer, como a do próprio Lutero. Entre os teólogos, o tema Lutero e Müntzer era concebido a partir da ótica do verdadeiro e falso profeta. Marxistas concebiam Müntzer como líder revolucionário engajado na libertação das massas exploradas e Lutero como traidor de "todos os elementos democrático-revolucionários". Segundo Fischer, a pesquisa "recente" concebe Lutero e Müntzer como personagens históricos complementares. Ambos buscaram responder aos problemas do século XVI, perpassados por dilemas. Por essa razão, conclui o autor, faz-se necessário considerar o contexto dos problemas e dos personagens do século da Reforma para uma interpretação adequada de ambos os reformadores. ${ }^{8}$

\section{Lutero e as comemorações de seu quingentésimo aniversário de nascimento}

Em 1983, ano de comemorações do quingentésimo aniversário de Martim Lutero, Estudos Teológicos publicou vários artigos sobre a atualidade da teologia luterana. Karl Gottschald apresenta um artigo sobre $O 500^{\circ}$ Aniversário de Lutero. Segundo Gottschald, o quingentésimo aniversário de Lutero evidenciou como tais festividades estão condicionadas pela "constelação histórica de cada época e das convicções ou dos interesses dos seus intérpretes ou avaliadores" ". Resgatando as festividades em torno do quadringentésimo aniversário de Lutero (1883), o autor destaca que, à época, as igrejas evangélico-luteranas ainda estavam fortemente impactadas pela promulgação do dogma da infalibilidade papal (1870) e pela publicação de um livro católico-romano ${ }^{10}$ com pesadas ofensas contra Martim Lutero (1881). Nesse contexto, o espírito das comemorações do aniversário de Lutero teve caráter confessional e

\footnotetext{
7 FISCHER, Joachim. Marcas Teológicas da Reforma Protestante. Estudos Teológicos, São Leopoldo, v. 28, n. 2, p. 121-135, 1988. p. 134-135.

8 FISCHER, Joachim. Lutero e Müntzer. Estudos Teológicos, São Leopoldo, v. 29, n. 1, p. 7-15, 1989. p. 14-15.

9 GOTTSCHALD, Karl. O 500 Aniversário de Lutero. Estudos Teológicos, São Leopoldo, v. 23, n. 1, p. 5-10, 1983. p. 5.

10 Trata-se do livro de Johannes Janssen, Geschichte des deutschen Volkes seit dem Ausgang des Mittelalters ("História do Povo Alemão desde o Fim da Idade Média") (1881).
} 
antirromano. Para Gottschald, a figura de Lutero, por ser "um gênio dotado de extraordinários e múltiplos talentos", fomentou as mais diversas recepções e interpretações, sejam de veneração, idealização, crítica ou condenação. O reformador foi concebido como excelente teólogo, pastor e pregador, corajoso e defensor da causa evangélica na esfera pública, revolucionário, humanista, tradutor da Bíblia, criador do hino evangélico, poeta, precursor do racionalismo, herói nacional, libertador dos preconceitos medievais e clericais, símbolo do progresso, divisor da cristandade, inimigo dos judeus, capacho dos príncipes etc. Finalizando seu artigo, o autor destaca os eventos que estariam sendo preparados nas "duas Alemanhas", nos Estados Unidos da América e também no Brasil sob o tema geral "Temer e amar a Deus e confiar nEle sobre todas as cousas". Entre os eventos, o autor destaca alguns de caráter ecumênico, na Alemanha, envolvendo teólogos católico-romanos, luteranos, reformados, menonitas, anglicanos, metodistas e ortodoxos. Esses eventos, comparados às festividades do quadringentésimo aniversário do reformador, evidenciam, segundo o autor, que "o tempo realmente parece estar maduro para que todos juntos, sem preconceitos, nos esforcemos para conseguir uma interpretação comum dos aspectos essenciais da teologia de Lutero, correspondendo assim à sua intenção original e, sobretudo, à vontade de Deus"'11.

No mesmo número de Estudos Teológicos de 1983, Silvio Meincke, em artigo intitulado Justificação por Graça e Fé: Um novo espaço para a vida, analisa a doutrina da justificação de Lutero, afirmando que ela não é uma das doutrinas da dogmática, mas é central para a promoção da vida, afrontando realidades que ameaçam e estrangulam a vida. A justificação por graça mediante a fé mantém sua atualidade como articuladora da vida. Pela justificação por graça mediante a fé, o ser humano é liberto para colocar recursos e meios a serviço da promoção da vida, conclui Meincke. ${ }^{12}$

Também Lindolfo Weingärtner apresenta um artigo nesse número de Estudos Teológicos, intitulado Identidade Luterana. Para Weingärtner, a teologia luterana, diferentemente dos movimentos de "cura divina" e religiosos entusiastas "que acobertam a podridão do velho homem", se apresenta com "sobriedade" e "lucidez". Essa sobriedade, para o autor, não somente é identidade a ser testemunhada no âmbito espiritual, mas também no âmbito político, "profano". Concluindo seu artigo, o autor afirma:

O que vale no campo religioso valerá também no campo profano. O cristão Luterano enfrentará com sobriedade e com a lucidez que é fruto do próprio evangelho - tanto uma ideologia "de direita" que faz o homem agarrar-se a posses materiais e a posições de poder, como uma ideologia "de esquerda", que pretende criar um paraíso na terra, sonhando com um mundo justo, sem apontar a podridão básica do homem e da sociedade, e sem falar de juízo e salvação transcendentais, "baralhando" as coisas do reino de Deus com as do mundo. Rejeitará qualquer tipo de polarização entre cristãos "piedosos" e cristãos "socialmente engajados", pois não ignora que os frutos da vivência

${ }^{11}$ GOTTSCHALD, 1983, p. 10.

12 MEINCKE, Silvio. Justificação por Graça e Fé: Um novo espaço para a vida. Estudos Teológicos, São Leopoldo, v. 23, n. 3, p. 205-230, 1983. p. 229-230. Sobre a doutrina da justificação em Lutero, veja também artigo de BRAKEMEIER, Gottfried. A Justificação por Graça e Fé em Paulo e sua relevância hoje. Estudos Teológicos, São Leopoldo, v. 16, n. 1, p. 3-17, 1976. 
cristã não devem ser cortados de suas raízes e que a ação social responsável faz parte da nova obediência do cristão ${ }^{13}$.

\section{Lutero e ecumenismo}

A teologia de Lutero, em particular, sua eclesiologia, precisa ser interpretada em perspectiva ecumênica. Em 1966, Joachim Fischer analisa O Conceito "Igreja" de Lutero segundo seus Escritos "Dos Concílios e da Igreja" e "Contra Hans Wurst". Segundo Fischer, a eclesiologia a partir de Lutero necessita responder à seguinte pergunta do reformador: "O que, quem, e onde a igreja esteja"14. Essa pergunta indica o caráter da igreja, seus membros e o lugar da igreja. As três dimensões, por sua vez, estão implicadas mutuamente: ao se falar do caráter da igreja, também se precisa falar de seus membros e seu lugar. E assim por diante. Para Lutero, em primeiro lugar, a palavra "igreja" não expressa o sentido pleno. As palavras grega "ekklesia" e alemã "Kirche" expressam "um povo reunido", mas não que essa igreja é "um povo especialmente indicado", que se distingue dos outros "povos". Segundo Lutero, outros conceitos expressam melhor "o que é a igreja", a saber, "a santa cristandade", "toda a cristandade", "um povo santo e cristão", "povo de Deus", a "ordem geral de Cristo", "a multidão de cristãos crentes" ou ainda "a comunidade e número ou reunião de todos os cristãos em todo o mundo, a única noiva de Cristo e seu corpo espiritual, do qual Êle [sic] é a única cabeça". Somente esses conceitos correspondem "à confissão da fé à igreja santa, católica e cristã". Para Lutero, possivelmente contra o sentido original, a fórmula latina do Credo Apostólico "sanctorum communio" deve ser traduzida como "comunhão" ou "comunidade dos santos". O caráter da igreja, portanto, é de comunhão de pessoas, pois implica caráter pessoal da igreja. Em segundo lugar, para Lutero a pergunta da eclesiologia precisa encontrar resposta sobre onde está a igreja, o povo santo e cristão de Deus. A resposta precisa indicar o seu lugar no mundo e na história, testemunhando a santidade recebida pelo Espírito Santo. "Somente uma cousa faz a igreja santa: a palavra externa e oral de Deus, pela qual o Espírito Santo faz a sua obra"15.

Em artigo de 1963, Tappenbeck anunciava, no artigo intitulado $A$ Sagrada Escritura e a lgreja sob o ponto de vista protestante, seu retorno à Alemanha, encerrando sua atividade docente na Faculdade de Teologia de São Leopoldo. Engajado na causa do ecumenismo, ele afirma que levaria para sua terra natal as lembranças e experiências dos diálogos que vivenciou entre a Faculdade de Teologia e o Seminá-

13 WEINGÄRTNER, Lindolfo. Identidade Luterana. Estudos Teológicos, São Leopoldo, v. 23, n. 3, p. 265 273, 1983. p. 273.

${ }^{14}$ LUTERO, Martim apud FISCHER, Joachim. O Conceito "Igreja" de Lutero segundo seus Escritos "Dos Concílios e da Igreja" e "Contra Hans Wurst”. Estudos Teológicos, São Leopoldo, v. 6, n. 4, p. 161-175, 1966. p. 161.

${ }^{15}$ FISCHER, 1966, p. 175. 
rio Maior de Viamão, que ocorria desde $1957 .{ }^{16}$ Oferecendo seu estudo sob o título supracitado, Tappenbeck resgata a afirmação de Lutero diante da Dieta de Worms, no ano de $1521,{ }^{17} \mathrm{e}$, relacionando-a com o princípio do "sola scriptura", questiona, com palavras de Otto Dibelius, se "hoje em dia não mais vale[ria] a pena manter disputas com católicos ou anglicanos quanto à relação entre Escritura e Tradição"18. Tappenbeck, em princípio, concorda com Dibelius, mas faz a ressalva de que o diálogo vale a pena. E o diálogo deve se dar, conforme o propõe Albert Lang, em torno da seguinte questão comum a luteranos e católicos: "É a Bíblia e pode ela ser ainda hoje um livro com o qual se vive?".

Em Lutero na Opinião da Igreja Católica Apostólica Romana (1961), Harding Meyer, citando [John A.] O'Brien, resgata a teologia do reformador de Wittenberg como uma "ponte ligando as nossas divergências", uma "fôrça [sic] que leva a uma união de mentes na fé"19. Meyer parte da constatação de que a historiografia, em especial a respeito de determinados eventos, precisa ser reexaminada, pois, no decorrer dos séculos, foram fixadas "verdades" que, repetidas vezes, se tornaram preconceitos e obstaculizaram o ecumenismo. Por isso Meyer resgata autores católico-romanos que, embora reconheçam divergências teológico-confessionais até como legítimas, percebem possibilidades de pontes, a partir da teologia de Lutero, para o ecumenismo. Destaque Meyer dá ao pensamento de Carlos Adam, citando-o:

Encontramos, ao meu ver, a formulação mais memorável numa obra do teólogo católico Carlos ADAM. Diz êle [sic]: "Partindo de Lutero, temos que lançar a ponte sôbre [sic] o abismo entre as confissões. Podemos até ousar o paradoxo: unicamente o regresso resoluto de nossos irmãos separados para Lutero possibilitará um regresso para a Igreja mãe [sic]".

Bem, sabemos todos que apenas uma aproximação no juízo sôbre [sic] a pessoa de Lutero ainda não anula as diferenças teológicas entre as confissões. As divergências doutrinárias ainda permanecem ${ }^{20}$.

O contexto da escrita do artigo de Meyer, ressalte-se, é o do pré-Concílio Vaticano II, quando já se percebe uma abertura da Igreja Católica Romana ao ecumenismo. Essa abertura é constatada por Meyer, afirmando que se vive "[...] uma nova época, na qual é possível manter um diálogo num espírito pacífico e objetivo, não alte-

16 TAPPENBECK, Heinrich. A Sagrada Escritura e a Igreja sob o ponto de vista protestante. Estudos Teológicos, São Leopoldo, v. 3, n. 4, p. 119-128, 1963. p. 119.

17 "A menos que seja vencido por testemunho das Escrituras ou por razão evidente - pois não creio somente no Papa nem nos concílios, pois é um fato que êles já têm errado e várias vêzes contradito a si mesmos - não posso nem quero revogar nada, vencido pelas palavras da Escritura que citei e tendo minha consciência captada nas palavras de Deus; porque agir contra a consciência não é nem destituído de perigos nem sincero. Aqui estou; de outra maneira não posso. Que Deus me ajude. Amém.” Apud TAPPENBECK, 1963, p. 119. Acentuação conforme no original.

18 DIBELIUS, Otto apud TAPPENBECK, 1963, p. 127.

${ }^{19}$ MEYER, Harding. Lutero na Opinião da Igreja Católica Apostólica Romana. Estudos Teológicos, São Leopoldo, ano 1, n. 1, p. 13-26, 1961. [Número Especial]. p. 27.

${ }^{20}$ MEYER, 1961, p. 27. 
rado pelo ódio e pelo fanatismo"21. Segundo Meyer, Lutero estaria se tornando, nesse contexto, fator de união, o que merece reconhecimento por parte do protestantismo.

Também Ricardo Pietrantonio, em A Liberdade Cristã e os Processos Históricos de Libertação (1990), estuda o diálogo ecumênico no contexto latino-americano. Segundo o autor, em diversas partes do Terceiro Mundo têm ocorrido lutas por transformações radicais do sistema sócio-político-econômico. Essas lutas trazem perguntas sobre o envolvimento da pessoa e da igreja cristãs nos processos históricos de libertação. Nesse contexto, o autor resgata o conceito de liberdade cristã de Lutero, ressaltando a necessidade de concebê-lo para além da dimensão individualista. ${ }^{22}$ Em sua conclusão, Pietrantonio questiona a razão pela qual, nos últimos séculos, a doutrina protestante da justificação pela fé acarretou em nível de vida melhor para os povos impactados pela Reforma, enquanto povos ensinados que Deus julgará por méritos não obtiveram êxito em aumentar o nível de vida de sua população. A isso o autor ensaia uma resposta, segundo a qual os primeiros teriam atuado muito mais para "dentro" do que para "fora" em termos de solidariedade. Faz-se necessário, segundo o autor, incorporar às dimensões econômica, social e política o critério da solidariedade, como Lutero a concebeu na segunda parte de seu escrito Da Liberdade Cristã, a saber, como critério derivado da gratuidade da salvação. Nesse caso, seria concebida uma "espiritualidade da sociedade" (não reduzida ao indivíduo), tornando-se mensagem evangélica ecumênica e abrangente para o mundo como um todo. Sem essa concepção ecumênica, conclui Pietrantonio, o mundo não tem nenhuma chance e a existência humana fica fadada ao destino trágico. Enquanto verdadeiramente ecumênica, a liberdade cristã é, portanto, a alternativa possível para a existência humana. ${ }^{23}$

\section{Lutero e a América Latina}

Em diversos momentos, autores de Estudos Teológicos recorrem a Lutero, buscando reler sua teologia ou resgatar sua atualidade. Hermann Brandt, em As tensões como uma oportunidade: a importância dos cnflitos na teologia e na Igreja $(1971)^{24}$, constata que a igreja cristã sempre viveu em realidades tensionadas e conflitivas. A imagem de uma igreja isenta de controvérsias internas seria uma construção posterior idealizada. As confissões de fé têm seu lugar de nascimento nas realidades conflitivas. Para Brandt, as tensões não caracterizam somente as relações entre "diferentes blocos confessionais", mas também desafiam "a unidade e a harmonia dentro das próprias Igrejas individuais". A história registra excomunhão como resultado de realidades conflitivas, mas também não menos tensionada podem ser realidades internas de igrejas individuais.

\footnotetext{
21 MEYER, 1961, p. 27.

22 PIETRANTONIO, Ricardo. A Liberdade Cristã e os Processos Históricos de Libertação. Estudos Teológicos, São Leopoldo, v. 30, p. 41-63, 1990. [Número Especial]. p. 41.

23 PIETRANTONIO, 1990, p. 58-59.

${ }^{24}$ O artigo é resultado da "Preleção inaugural proferida na Faculdade de Teologia a 10 de novembro de 1971".
} 
Dentro das Igrejas evangélicas, por exemplo, há grupos progressistas que se sentem mais próximos aos grupos progressistas católicos do que aos elementos conservadores de suas próprias fileiras. As tensões existem em todo e qualquer lugar. Elas são uma realidade concreta dada. O conflito não só é um fato internacional, mas também um fato ecumênico. ${ }^{25}$

Para Brandt, os conflitos e as tensões evidenciam a própria incapacidade humana de solucioná-los. Não por último, conflitos e tensões evidenciam a separação entre ser humano e Deus, resultado do pecado. Diante disso, Jesus Cristo é a revelação do projeto original de unidade entre Deus e ser humano. O reconhecimento e a confissão de fé dessa revelação permitem ter paz em meio às realidades conflitivas e tensionadas. Jesus Cristo é a "exceção" que nos permite experimentar a própria "graça como sendo exceção" 26 . Considerando essa paradoxalidade de conflito e paz, Brandt evoca Lutero, segundo o qual:

A vida cristã não consiste em ser, mas em tomar-se, não na vitória, mas na luta, não na justiça, mas na justificação. Nós ainda não o somos, mas nós o seremos. Ainda não está feito e consumado, mas está a caminho. Não é o fim, mas é o meio. Nem tudo já reluz e brilha, mas tudo está melhorando ${ }^{27}$.

Um outro artigo que classificamos como releitura da teologia de Lutero para a América Latina é de autoria de Martin N. Dreher, intitulado A Igreja no Brasil diante do Problema Social do Pequeno Agricultor e do Operário: Uma Perspectiva Histórica. Nesse artigo, Dreher analisa a relação entre trabalho e descanso. O fato de trabalho implicar "canseira, preocupações e decepções" tem a ver, por um lado, com a realidade de pecado humano - "no suor do teu rosto" (Gn 3.19). Mas, por outro lado, o trabalho também está sob a benção de Deus - "Podes comer do trabalho de tuas mãos; és feliz. Tudo te irá bem" (S1 128.2). Contudo, Dreher também ressalta que, assim como o trabalho encontra fundamento no mandamento e na vontade de Deus, encontra também aí sua delimitação pelo descanso (Sabbath). O autor, então, resgata uma carta a Filipe Melanchthon, datada de 12 de maio de 1530, onde Lutero escreve que "também se serve a Deus com descanso; e, com nada mais do que descanso" 28 . Colocando-se o descanso acima do trabalho, segundo Dreher, o ser humano deixa Deus ser Deus, pois, no descanso, o ser humano evidencia sua confiança posta em Deus, na certeza de que ele continua agindo enquanto a pessoa descansa. "Com esta valorização do descanso chegamos a uma demitização do trabalho com o qual se pensa tudo conseguir e com o qual se luta, desesperadamente, para algo conseguir." 29 A

${ }^{25}$ BRANDT, Hermann. As tensões como uma oportunidade: A importância dos conflitos na teologia e na Igreja. Estudos Teológicos, São Leopoldo, v. 12, n. 1, p. 10-26, 1971. p. 10-11.

26 BRANDT, 1971, p. 26.

27 Apud BRANDT, 1971, p. 26.

28 Apud DREHER, Martin N. A Igreja no Brasil diante do Problema Social do Pequeno Agricultor e do Operário: Uma Perspectiva Histórica. Estudos Teológicos, São Leopoldo, v. 21, n. 2, p. 119-135, 1981. p. 135.

29 DREHER, 1981, p. 135. 
pregação do descanso, contudo, não visa àquelas pessoas em situações de vulnerabilidade, em particular, ao pequeno agricultor e ao operário, mas àqueles que exploram com baixos salários e provocam a expulsão da terra. Por isso

Ele é o Deus do descanso, do lazer; ele quer que meu lazer seja também o lazer do próximo. Para este lazer é necessário que eu deixe que chegue ao próximo a terra que Ele deu a todos nós e que os bens desta terra possam por todos nós ser trabalhados para seu louvor ${ }^{30}$.

Em 1978, Vítor Westhelle, em Considerações sobre o etno-luteranismo latino-americano: panfleto para debate, aborda o desafio das "igrejas de transplante", em particular a IECLB, em afirmar sua identidade em regiões onde não se encontra grande concentração de descendentes de imigrantes europeus. Analisando a teologia dos dois regimentos (espiritual e secular) de Lutero, Westhelle afirma:

A manutenção da distinção metodológica de competências, para Lutero, foi tão importante como a situação criativa de encontro de ambas as dimensões. Nesse contexto, a igreja define a sua função mediadora com especificidade, embora não fosse a única instância mediadora (há ainda o indivíduo e a escatologia). Não sendo idêntica ao regimento espiritual, a igreja é a representação ou a dimensão de serviço desse regimento. Por isso, ela não constitui poder ou autoridade, segundo Lutero ${ }^{31}$.

Considerando a igreja na perspectiva de "serviço", "por onde flui a essência espiritual", Westhelle afirma que "a encarnação da Palavra no povo define a configuração da igreja. Isto é o que chamamos pastoral popular" 32 . Como "serviço", a igreja se concretiza em forma institucional. A confusão dos regimentos, por sua vez, resulta em a forma passe a se sobrepor, isto é, que a forma passe a ideologizar a substância, ao contrário da verdadeira igreja de Cristo que formata forma a partir da essência. ${ }^{33}$ Westhelle constata que, no caso do "etno-luteranismo", “[...] até hoje não conseguiu impor um caráter de catolicidade, mas permanece com o um arquipélago de ilhas isoladas: as comunidades" ${ }^{34}$. Desta forma, "[...] o luteranismo conseguiu um transplante com fortes sintomas de rejeição e evitou a encarnação, resultando numa confusão de regimentos" 35. Westhelle, então, defende que "a pastoral precisa ser retomada na igreja como a dimensão de serviço-culto do regimento espiritual" 36 .

Também ensaiando releitura de Lutero, Marlon R. Fluck analisa a Hermenêutica em Lutero. Um estudo fundamentado em "À nobreza cristã de nação alemã, acerca

\footnotetext{
${ }^{30}$ DREHER, 1981, p. 135.

31 WESTHELLE, Vítor. Considerações sobre o Etno-luteranismo Latino-americano: panfleto para debate. Estudos Teológicos, São Leopoldo, v. 18, n. 2, p. 77-94, 1978. p. 89.

32 WESTHELLE, 1978, p. 93.

33 WESTHELLE, 1978, p. 90-91.

34 WESTHELLE, 1978, p. 91.

35 WESTHELLE, 1978, p. 92.

36 WESTHELLE, 1978, p. 93.
} 
do melhoramento do estado cristão" (1986). O autor parte do pressuposto hermenêutico de "que todo escrito ou visão hermenêutica estão vinculados à experiência de vida do autor dos mesmos" 37 . Após contextualizar e analisar o escrito de Lutero, o autor oferece três teses para uma hermenêutica latino-americana a partir da pergunta: "O que um homem do século XVI pode ainda contribuir para nosso fazer teologia no século XX?" ${ }^{38}$. Na primeira tese, o autor defende que não se deve simplesmente repetir Lutero, pois sua cultura, formação teológica e social o prendem ao século XVI. Por serem os problemas de Lutero diferentes dos "nossos", "isto nos liberta para a busca por novos caminhos". Isso não significa - segunda tese - que se pode abrir mão do ponto de referência. A Sagrada Escritura é essa referência, que, em perspectiva luterana, nos permite multiplicar "sinais de esperança do Reino, historicamente situados". Finalmente - terceira tese -, uma hermenêutica que se pretende denominar contextualizada pressupõe integridade intelectual que cumpra a responsabilidade de proclamar as verdades cristãs no tempo e na situação, em particular, do povo brasileiro. Concluindo, o autor afirma:

Ele [Lutero] nos incentiva a empreendermos tentativas que visem a uma tradução mais fiel do evangelho do reino de Deus para dentro de nossa cultura. A convicção de Lutero de que é graças à ação do Espírito Santo que o evangelho se contextualiza persistente como convicção fundamental, visto que contextualizar não é apenas estar de ouvidos atentos para ouvir o que a cultura do povo ricamente nos ensina, mas também é ouvir Deus, que quer que a vida do povo se conforme à sua vontade. Contextualização testemunha, portanto, do Deus que está em missão entre o seu povo; é encarnação. Hermenêutica que não leva, portanto, a igreja ao engajamento missionário não pode ser chamada de contextual. Neste ponto, Lutero novamente nos desafia, pois não poderia ser descrito como hermeneuta da escrivaninha. Ele é, isto sim, hermeneuta do caminho. Todos nós somos chamados a redescobri-lo hoje! ${ }^{39}$.

Vítor Westhelle, em Desencontro entre a Teologia Luterana e a Teologia da Libertação (1986), constata existirem conflitos de duas ordens em relação à última. De um lado, existiria uma certa "fascinação emotiva" por ela, de outro, seria percebida "[...] como a fonte de expiação sacrificial para uma consciência teológica sobrecarregada o de culpa e perdida nas ambivalências políticas e culturais da fase tardia do capitalismo". A teologia luterana, em particular, perceberia a teologia da libertação como não levando suficientemente a sério a realidade do pecado humano, reduzindo-o às expressões socioeconômicas. ${ }^{40}$ Para Westhelle, embora possam parecer mutuamente excludentes, ambas as teologias não seriam completamente incompatíveis. Nessa

${ }^{37}$ FLUCK, Marlon R. Hermenêutica em Lutero. Um estudo fundamentado em "À nobreza cristã de nação alemã, acerca do melhoramento do estado cristão”. Estudos Teológicos, São Leopoldo, v. 26, n. 2, p. $145-168,1986$. p. 145.

38 FLUCK, 1986, p. 167.

39 FLUCK, 1986, p. 168.

40 WESTHELLE, Vítor. Desencontro entre a Teologia Luterana e a Teologia da Libertação. Estudos Teológicos, São Leopoldo, v. 26, n. 1, p. 37-58, 1986. p. 37. 
perspectiva, a concepção de Lutero sobre o uso público da razão como práxis comunicativa e emancipatória permite a reconstrução da dimensão sociopolítica, de forma que " [...] ao incluir na conversação o marginalizado, cria o fôro [sic] no qual se faz possível ouvir a palavra de novidade que surge como a voz estranha da vítima das próprias convenções legais e morais" ${ }^{41}$. Concluindo, o autor afirma que isso

não faz de Lutero um teólogo da libertação. O que faz é abrir a possibilidade de um diálogo que viabilize a reconstrução teológica que cada época exige, a mesma reconstrução que Lutero buscou no seu contexto, desafiado por problemas característicos de sua época ${ }^{42}$.

Ainda em 1986, Gottfried Brakemeier dialoga com pontos levantados por Westhelle no artigo supracitado. Segundo Brakemeier, ambas as teologias (luterana e da libertação) carecem de revisão. Segundo ele, ambas as teologias giram em torno de um tema comum: a doutrina da justificação. ${ }^{43}$ E sua conclusão, o autor salienta que

\begin{abstract}
se a teologia luterana, em muitos dos seus representantes, subestimou a função e a importância da lei civil, a teologia está no perigo de super-estimá-la [sic]. Pois, o que se pode de fato alcançar mediante leis, estruturas e sistemas? Muito, sem dúvida alguma - mas não a novidade escatológica. Esta provém unicamente da Palavra do Evangelho. Por isto mesmo julgo também que "a origem possível do falar de Deus" não é a "integração na práxis comunicativa daquele que foi calado", mas sim a ação de Deus em Cristo, da qual o Evangelho dá notícia. No início de nosso falar de Deus está a práxis do ouvir da mensagem do Cristo $^{44}$.
\end{abstract}

Martin N. Dreher apresenta, em 1988, um ensaio de releitura da teologia luterana em $A$ theologia crucis de Lutero e o tema da Teologia da Libertação. ${ }^{45}$ Para o autor, as duas teologias têm identidades comuns, por serem essencialmente práticas e, para serem compreendidas e assimiladas, exigem o imperativo da "com-paixão" com as pessoas sofredoras. Ambas, theologia crucis e teologia da libertação, vivem o lugar da morte, assemelhando-se à cruz. Elas apontam para o discipulado sob a cruz, vivenciando a experiência do abandono, da fraqueza, do desespero, mas orientado pela esperança do evento pascal. Pessah, do hebraico, aponta para "saída", saída da morte para a vida. E esse movimento em direção à vida revela a própria vontade de Deus. Como vida, o sofrimento também não é concebido como ascese, mas como caminho que é vida na opressão (humilitas), na tentação e em oração constante. Para o autor, no diálogo com a teologia da libertação, a teologia luterana precisa redescobrir suas

41 WESTHELLE, 1986, p. 57.

42 WESTHELLE, 1986, p. 58.

${ }^{43}$ BRAKEMEIER, Gottfried. Desencontro entre a Teologia Luterana e a Teologia da Libertação? (carta de leitor). Estudos Teológicos, São Leopoldo, v. 26, n. 3, p. 309-313, 1986. p. 310.

44 BRAKEMEIER, 1986, p. 312. Sobre a teologia da libertação veja ainda artigo de ALTMANN, Walter. Teologia da Libertação. Estudos Teológicos, São Leopoldo, v. 19, n. 1, p. 27-35, 1979.

45 DREHER, Martin N. A theologia crucis de Lutero e o tema da Teologia da Libertação. Estudos Teológicos, São Leopoldo, v. 28, n. 2, p. 137-152, 1988. p. 138-139. 
próprias raízes, “[...] a partir da justificação por graça e fé, que possibilita a superação de egoísmo e de falta de amor"46.

Em 1989, em novo artigo, Dreher analisa A Autoridade Secular: a visão de Lutero, buscando uma "releitura de Lutero no Brasil". O autor ressalta que é necessário interpretar o pensamento de Lutero sobre o tema da autoridade de forma distinta após a Dieta de Worms (1521), após a Dieta de Espira (1529) e após a convocação do Concílio pelo papa Paulo III (1536). Igualmente é preciso atentar à recepção de Lutero sobre o tema, razão pela qual o autor apresenta interpretações de Lutero oferecidas por Eivind Beggrav, bispo da Igreja da Noruega durante a ocupação do seu país pelo regime nazista alemão (1940-1945) e à luz da história do Brasil. Dreher conclui que, na Alemanha nazista, acabou-se por fundar um sistema de Estado que controlou luteranos. Esqueceu-se, naquele contexto, do pensamento de Lutero sobre os limites da autoridade. A igreja, os púlpitos, as escolas e cátedras de teologia foram utilizados para produzir súditos fiéis e subalternos. Muitos desses súditos vieram ao Brasil como imigrantes, segundo Dreher, e reproduziram aqui esses pensamentos, a despeito das condições políticas que não lhes era favorável como religião minoritária e, até 1889/1891, somente tolerados no Império do Brasil. ${ }^{47}$

Em 1990, Albérico Baeske apresenta uma Releitura de Lutero em Contextos de Terceiro Mundo: Reflexões de um pastor que trabalha no centro geodésico da América do Sul sobre o aproveitamento da teologia de Martim Lutero para a militância cristã no Terceiro Mundo. O autor escreve impactado pela miséria que destrói a solidariedade entre oprimidos e desfaz movimentos populares. A partir desse contexto, Baeske pergunta: "O que Martim Lutero, teólogo alemão na passagem da Idade Média para a Moderna, tem a ver com o Terceiro Mundo?"48. O autor lembra que Lutero insistia que uma pessoa cristã deve utilizar poucas palavras e empreender muitas ações, pois ações visam ao bem comum, em especial, ao pão e ao trabalho. Para o reformador, a pessoa cristã deve colocar "corpo, bens e honra" a serviço do próximo. Somente uma pessoa liberta pela fé assume responsabilidade e compromisso com o próximo. Disso, conclui Baeske, a teologia de Lutero tem sua atualidade para o Terceiro Mundo, ao afirmar que a fé produz liberdade cristã, e liberdade para servir. Liberto para servir, a pessoa cristã “[...] vai à luta, aliás, participa na luta por pão e saúde, por teto e terra, por escola, vida partilhada e estruturação popular, transparente e mutável da sociedade"49.

${ }^{46}$ DREHER, 1988, p. 152.

${ }^{47}$ DREHER, Martin N. A Autoridade Secular: a visão de Lutero. Estudos Teológicos, São Leopoldo, v. 29, n. 1, p. 69-86, 1989. p. 85-86.

48 BAESKE, Albérico. Releitura de Lutero em Contextos de Terceiro Mundo: Reflexões de um pastor que trabalha no centro geodésico da América do Sul sobre o aproveitamento da teologia de Martim Lutero para a militância cristã no Terceiro Mundo. Estudos Teológicos, São Leopoldo, v. 30, p. 15-35, 1990. [Número Especial]. p. 15.

49 BAESKE, 1990, p. 30. 


\section{Lutero e a Igreja Evangélica de Confissão Luterana no Brasil - IECLB}

Em Estudos Teológicos, também encontramos artigos que dialogam mais diretamente com a realidade da Igreja Evangélica de Confissão Luterana no Brasil IECLB. Um desses artigos, de autoria de Walter Altmann, em Identidade na Comunhão de jornada: reflexões sobre a identidade da IECLB (1974), analisa a IECLB no contexto do movimento ecumênico mundial. Em sua conclusão, o autor destaca o perigo do aniquilamento na multiplicidade, mas também o imperativo da legitimidade da pluralidade, considerando que a igreja se fez em realidade de diversidade, conforme relatos da vida do próprio Jesus Cristo. ${ }^{50}$

Também Wilhelm Hüffmeier, Batismo - Meio de salvação ou selo da justificação? Observações sobre a compreensão sacramental e não-sacramental do Batismo na perspectiva do Novo Testamento (1973), analisa a dimensão da unidade, a partir do tema do batismo. O autor contata que existem "problemas" em torno do batismo no âmbito da IECLB. Hüffmeier constata que, à época, o Concílio do Distrito Eclesiástico Norte do Espírito Santo havia decidido promover uma "conscientização em massa do que é Batismo". Constatava-se que havia muitas superstições e práticas mágicas em torno do batismo. Segundo Hüffmeier, a crise em torno do batismo é tão antiga quanto o cristianismo. Não se pode conceber que o batismo tivesse sido realizado de forma uniforme ao longo da história da igreja cristã. Inclusive concepções mágicas do batismo podem ser verificadas ao longo da história do cristianismo; "[...] magia é tão antiga quanto a religião". Evidência disso é o batismo em favor de pessoas falecidas, aludidas pelo apóstolo Paulo em 1 Coríntios 15.29, evidenciando claros elementos mágicos. Cria-se que o batismo em favor de pessoas mortas, realizado de forma vicária, proporcionasse participação na ressurreição futura. Para Hüffmeier, "quando Cristo exerce o senhorio, toda magia chega tarde" $"{ }_{51}$. A partir disso, o autor conclui que é necessário ensinar que Cristo, e não a igreja, é o único sacramento e meio de salvação, sendo a igreja somente "receptora agradecida da salvação". Essa recepção se dá somente pela fé e é testemunhada como serviço a Cristo no mundo a partir da prática do amor. Esse é, segundo Hüffmeier, o cerne do batismo e assim deveria ser compreendido também na atualidade. De forma nenhuma deveria ocorrer em alguma comunidade da IECLB o que ocorreu no final do século XVI, conforme compartilha o autor ao final de seu artigo:

Em 1586, quando Cristiano I se tornou príncipe-eleitor na Saxônia luterana, ele aboliu, influenciado pelo seu esclarecido chanceler calvinista, Nicolau Krell, o exorcismo na celebração do Batismo. Os luteranos tinham o costume, como era corrente na Idade

${ }^{50}$ ALTMANN, Walter. Identidade na Comunhão de jornada: reflexões sobre a identidade da IECLB. Estudos Teológicos, São Leopoldo, v. 14, n. 2, p. 3-17, 1974. p. 3, 16.

${ }^{51}$ HÜFFMEIER, Wilhelm. Batismo - Meio de salvação ou selo da justificação? Observações sobre a compreensão sacramental e não-sacramental do Batismo n a perspectiva do Novo Testamento. Estudos Teológicos, São Leopoldo, v. 13, n. 2, p. 61-79, 1973. p. 62. 
Média, de "expulsar o demônio" durante o Batismo, a fim de que fosse anulada na criança a maldição do pecado original. Em muitas comunidades esse costume era mais importante que a doutrina correta de que acabara a maldição do pecado original. Consequentemente foi enorme a agitação no país, quando Cristiano I proibiu esse costume. Um açougueiro de Dresden veio armado com uma machadinha para o Batismo de seu filho e exigiu que fosse batizado com o "saia" (Fahraus). Antes de zombarmos da crença em diabos que está por detrás do exorcismo, deveríamos lembrar-nos da explicação do Batismo no Catecismo Menor de Lutero: "Que dá ou aproveita o Batismo? Resposta: Opera a remissão dos pecados, livra da morte e do diabo e dá a salvação eterna”. Portanto, por que não o exorcismo? Não sei se aquele açougueiro de Dresden trouxe além da machadinha também o Catecismo Menor de Lutero para o batismo de seu filho. Teria sido consequente. Contudo o Catecismo Menor de Lutero não pode ter a última palavra nessa questão ${ }^{52}$.

\section{Considerações finais}

Nosso objetivo foi analisar artigos sobre Lutero e teologia luterana publicados em Estudos Teológicos entre os anos de 1961 e 1990. Utilizamos, como critério de escolha, artigos que apresentam ensaio de interpretações sobre a própria Reforma, sua história e controvérsias, e ensaios de diálogo com a realidade latino-americana, ecumenismo e vida da Igreja Evangélica de Confissão Luterana no Brasil - IECLB. As três décadas (1961-1990) de que datam os artigos são historicamente muito complexas na perspectiva política, social, econômica e religiosa. Analisar, portanto, cada um dos artigos referenciados neste estudo demandaria outro estudo, que certamente valeria a pena. Em sentido geral, contudo, conclui-se que, durante as três décadas, Estudos Teológicos se apresentou como veículo de destaque de uma instituição de formação teológica para apresentar a teologia de Lutero e luterana e dialogar com a realidade latino-americana. Evidencia-se que os artigos buscam apresentar aspectos da história da Reforma e da teologia de Lutero, em que a teologia luterana precisa ser articulada no espaço acadêmico (Faculdades de Teologia/Escola Superior de Teologia) e eclesial (IECLB) luteranos. Neste sentido, busca-se resgatar temas centrais da teologia luterana, seja para a afirmação identitária luterana, seja para fundamentar o testemunho luterano para além de suas fronteiras ante os desafios sociais, políticos, econômicos, ecumênicos no Brasil e, mais amplamente, na América Latina.

\section{Referências}

ALTMANN, Walter. Teologia da Libertação. Estudos Teológicos, São Leopoldo, v. 19, n. 1, p. 27-35, 1979.

. Identidade na Comunhão de jornada: reflexões sobre a identidade da IECLB. Estudos

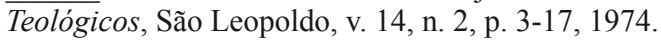

BAESKE, Albérico. Releitura de Lutero em Contextos de Terceiro Mundo: Reflexões de um pastor que trabalha no centro geodésico da América do Sul sobre o aproveitamento da teologia

${ }^{52}$ HÜFFMEIER, 1973, p. 78-79. 
de Martim Lutero para a militância cristã no Terceiro Mundo. Estudos Teológicos, São Leopoldo, v. 30, p. 15-35, 1990. [Número Especial].

BRAKEMEIER, Gottfried. A Justificação por Graça e Fé em Paulo e sua relevância hoje. Estudos Teológicos, São Leopoldo, v. 16, n. 1, p. 3-17, 1976.

Desencontro entre a Teologia Luterana e a Teologia da Libertação? (carta de leitor).

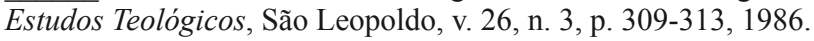

BRANDT, Hermann. As tensões como uma oportunidade: A importância dos conflitos na teologia e na Igreja. Estudos Teológicos, São Leopoldo, v. 12, n. 1, p. 10-26, 1971.

DOHMS, Hermann Gottlieb. Luther vive. São Leopoldo: Faculdade de Teologia, 1946.

DREHER, Martin N. AAutoridade Secular: a visão de Lutero. Estudos Teológicos, São Leopoldo, v. 29 , n. 1 , p. 69-86, 1989.

. A Igreja no Brasil diante do Problema Social do Pequeno Agricultor e do Operário: Uma Perspectiva Histórica. Estudos Teológicos, São Leopoldo, v. 21, n. 2, p. 119-135, 1981.

. A theologia crucis de Lutero e o tema da Teologia da Libertação. Estudos Teológicos, São Leopoldo, v. 28, n. 2, p. 137-152, 1988.

FISCHER, Joachim. Lutero e Müntzer. Estudos Teológicos, São Leopoldo, v. 29, n. 1, p. 7-15, 1989. Marcas Teológicas da Reforma Protestante. Estudos Teológicos, São Leopoldo, v. 28, n. 2, p. $121-135,1988$.

FISCHER, Joachim. O Conceito "Igreja" de Lutero segundo seus Escritos "Dos Concílios e da Igreja" e "Contra Hans Wurst". Estudos Teológicos, São Leopoldo, v. 6, n. 4, p. 161-175, 1966. FLUCK, Marlon R. Hermenêutica em Lutero. Um estudo fundamentado em "À nobreza cristã de nação alemã, acerca do melhoramento do estado cristão". Estudos Teológicos, São Leopoldo, v. 26, n. 2, p. 145-168, 1986.

GOTTSCHALD, Karl. O 500 Aniversário de Lutero. Estudos Teológicos, São Leopoldo, v. 23, n. 1, p. 5-10, 1983.

HÜFFMEIER, Wilhelm. Batismo - Meio de salvação ou selo da justificação? Observações sobre a compreensão sacramental e não-sacramental do Batismo na perspectiva do Novo Testamento.

Estudos Teológicos, São Leopoldo, v. 13, n. 2, p. 61-79, 1973.

LAU, Franz. A afixação das teses de Lutero: Lenda ou Fato? Trad. M. Siegle e M. Dreher. Estudos Teológicos, São Leopoldo, v. 7, n. 4, p. 170-185, 1967.

MEINCKE, Silvio. Justificação por Graça e Fé: Um novo espaço para a vida. Estudos Teológicos, São Leopoldo, v. 23, n. 3, p. 205-230, 1983.

MEYER, Harding. Lutero na Opinião da Igreja Católica Apostólica Romana. Estudos Teológicos, São Leopoldo, ano 1, n. 1, p. 13-26, 1961. [Número Especial].

PIETRANTONIO, Ricardo. A Liberdade Cristã e os Processos Históricos de Libertação. Estudos Teológicos, São Leopoldo, v. 30, p. 41-63, 1990. [Número Especial].

TAPPENBECK, Heinrich. A Sagrada Escritura e a Igreja sob o ponto de vista protestante. Estudos Teológicos, São Leopoldo, v. 3, n. 4, p. 119-128, 1963.

WEINGÄRTNER, Lindolfo. Identidade Luterana. Estudos Teológicos, São Leopoldo, v. 23, n. 3, p. $265-273,1983$.

WESTHELLE, Vítor. Considerações sobre o Etno-luteranismo Latino-americano: panfleto para debate. Estudos Teológicos, São Leopoldo, v. 18, n. 2, p. 77-94, 1978.

Desencontro entre a Teologia Luterana e a Teologia da Libertação. Estudos Teológicos, São Leopoldo, v. 26, n. 1, p. 37-58, 1986. 